\title{
From Emergency to the Community: Nursing Care That Promotes Safe Transition of the Person with Increased Vulnerability
}

\author{
Cristina Monteiro ${ }^{1}$, João Rosado ${ }^{2}$, Pedro Teixeira ${ }^{1}$ and Melissa \\ Fernandes ${ }^{1}$ \\ ${ }^{1}$ RN, Hospital Vila Franca de Xira, Lisboa - Urgência Geral | Cristina.monteiro@hvfx.pt | \\ https://orcid.org/0000-0001-7050-8801 | Pedro.teixeira@hvfx.pt | \\ https://orcid.org/0000-0002-6769-1753 | melisssa.fernandes@hvfx.pt | \\ https://orcid.org/0000-0002-0959-826X \\ ${ }^{2}$ RN, Centro Hospitalar Universitário de Lisboa Central, Lisboa -Unidade de Urgência Médica \\ joaorosado@campus.esel.pt | https://orcid.org/0000-0003-3769-4141
}

\begin{abstract}
Readmission to the emergency service after discharge is high, nursing interventions are needed in order to ensure continuity of care after discharge from this service to avoid this phenomenon. Objective: To identify the risk factors for readmissions and describe the interventions that guarantee continuity of care after discharge from the Emergency Department. Methodology: Integrative literature review, following the protocol. The bibliographic sample comprises 7 articles. Results: It is necessary to identify risk factors, personal history, polymedication, the current life situation, age, level of dependence, risk of falling and cognitive function. In nursing, the interventions that stand out the most are the follow-up telephone calls and the existence of an expert nurse in transitional care. Conclusion: The evidence recommends that the existence of structured interventions and an effective articulation of care between the Emergency Department and the Community are good practices to implement and bring health gains to the population studied, however there is a need to further research at this level.
\end{abstract}

Keywords: elderly; nursing care, continuity of care, transitional care, emergency.

\section{Introduction}

Over time, from 1996 to 2019, it has been verified that the Portuguese population has undergone a demographic aging resulting from multiple variables in the reality of this society. According to the demographic data contemplated by the National Statistics Institute (2017), it is predicted that between 2015 and 2080 the number of elderly people in Portugal will increase from 2.1 to 2.8 million and that, since this fact is accompanied with a decrease in the younger population, the aging rate will double, from 147 to 317 elderly people for every 100 young people, in 2080. And when compared, the population that uses the adult Emergency Room (ER) in Portugal, it is observed that the number of people aged 65 or over is higher than the number of people in other age groups, as indicated by Azeredo (2014). These data are important since, according to the definition of the World Health Organization (WHO, 2015), in developed countries the elderly is every person aged 65 or over. Associated with this aging, there is still a fragility consequent of the anatomicalphysiological changes that occur in the human organism. According to Azevedo (2015), the aging process intervenes in several dimensions, such as biological, psychological and social, where changes are identified at the organic level, at the behavioral level (such as changes in memory, motivation and intelligence) and an increase in the social isolation, which can lead to marginalization.

As indicated by Azeredo (2014) and Brazão, Nóbrega, Bebiano and Carvalho (2016), the ER (Emergency Room) are the first line of contact between the person and the other health services, and that the elderly population, increasingly fragile and where isolation can also be seen as a reality, uses the ES more for these reasons. According to the Portugal's Directorate-General for Health (Direção-Geral da Saúde, 2017) there is a need to provide differentiated care in an emergency situation in the ER since these situations directly contribute to a state of danger in the absence of care. 
In this context, according to Brazão, Nóbrega, Bebiano and Carvalho (2016), health care has become increasingly expensive in Portugal, and the overcrowding of the ER remains a current problem. The various interventions at the political level that have occurred in an attempt to reduce "indiscriminate and inappropriate" (Brazão et al., 2016, p.14) access to the ER, have not been effective, and it is necessary to go further, considering important good access to primary healthcare in the community. For this reason, it is essential to identify what are the risk factors for readmissions to the ER, after a first occurrence / admission and what are the strategies and interventions to be implemented that guarantee continuity of care after the discharge from the ER.

\section{Methodology}

An integrative literature review was carried out that "includes the analysis of relevant research that supports decision making and the improvement of clinical practice, enabling the synthesis of the state of knowledge of a given subject" (Mendes, Campos Pereira Silveira, \& Galvão, 2008, p. 759). The PICo mnemonic was used - where the (P) population, the (I) intervention and the (Co) context (The Joanna Briggs Institute, 2011) are considered to carry out the research question. The population we're studying are the elderly ( $\geq 65$ years), the intervention is the nursing care that promotes the safe transition, and the context is the Emergency Room and the Community. Thus, the following research question is obtained: "What nursing care promotes a safe transition between the Emergency Department and the Community?"

As an object of study, we intend to identify the risk factors for readmissions to the ER, after the first occurrence and which nursing care promotes a safe transition between the ER and the community, in the elderly. The inclusion criteria defined for the choice of studies are the dates of publications between 2014 and 2019, Portuguese or English, and the descriptors that were used. The exclusion criteria used, during the research, includes the exclusion of studies whose text is not available in full and studies in which the studied population includes children, adolescents or adults.

The data collection was carried out in several databases provided by ESEL (Escola Superior de Enfermagem de Lisboa), in order to achieve the objectives mentioned in the previous point. The search was then carried out in the following databases: MEDLINE Complete, CINAHL Complete, EBSCO Discovery Service Lisbon Nursing School. Other types of resources were also used, using the ESEL Library (Pole Calouste Gulbenkian) to search for articles from magazines, newspapers, other research works and information from institutional websites. The search was carried out by two researchers, independently. The descriptors used for the respective database search are: $(P)$ elderly (aged, frail elderly), (I) Nursing care (nursing care, prevention, interventions), (I) transition of care (continuity of care, transitional care), (Co) Emergency services, (Co) readmissions (patient readmission, patient discharge, outcome assessment).

In the research process, the descriptors were related to the Boolean as follows: S1 ("aged" or "frail elderly") and S2 ("nursing care" or "prevention" or "interventions") and S3 ("continuity of care "Or" transitional care ") and S4 (" emergencies "or" emergency service ") and S5 (" patient readmission "or" outcome assessment "or" patient discharge "). After searching the database, 98 articles were obtained, with 45 articles being excluded because they were duplicated, leaving 53 articles. After reading the title, 16 articles were excluded, and of the remaining articles, the abstract of each one was analyzed. After reading the abstract, 16 articles were excluded, considering the inclusion and exclusion criteria defined for the research (Figure 1). Thus, the number of articles was reduced to 21 articles for full reading, resulting in 5 articles, these being the articles selected for the Monograph. Two researchers carried out the codification and the other researchers assessed it to increase the reliability of the present study. Through other types of resources, such as the search through Google Academics, another 2 articles were selected, which makes a total of 7 articles. Of these 7 selected articles, their analysis and synthesis were performed (Figure 1). 


\section{Results}

In Figure 1, information about the authors and type of studies found is outlined, as well as the main results evidenced in each study.

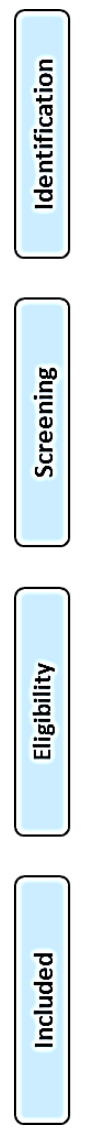

Records identified through database searching MEDLINE (38), CINAHL (22), Discovery Service ESEL (38) $(n=98)$

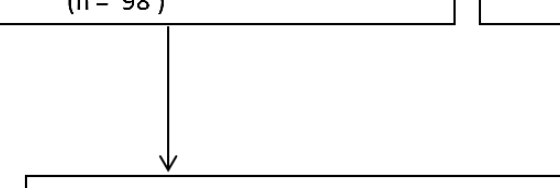

Records after duplicates removed $(n=55)$

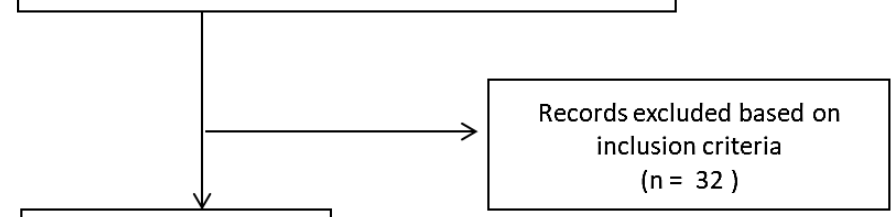

Full-text articles assessed for eligibility $(n=23)$

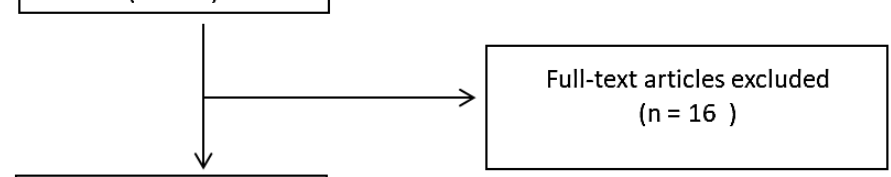

Studies included

$(n=7)$

Fig 1. Flowchart for the selection of articles for the integrative review, prepared based on the PRISMA recommendations. Lisbon.

Table 1. Bibliographic sample of RIL, Lisbon, 2019.

\begin{tabular}{|c|c|c|c|c|c|}
\hline Code & Author, year & $\begin{array}{l}\text { Type of } \\
\text { study }\end{array}$ & Participants & Objectives & Main results \\
\hline $\mathrm{E} 1$ & $\begin{array}{l}\text { Biese, K. J., } \\
\quad \text { Busby- } \\
\text { Whitehead, J., } \\
\text { Cai, J., Stearn } \\
\text { S.C., Roberts, } \\
\text { E., Mihas, P., } \\
\text { ‥ Kizer, J.S. } \\
\text { (2018) }\end{array}$ & $\begin{array}{l}\text { Randomized } \\
\text { controlled } \\
\text { trial }\end{array}$ & $\begin{array}{l}\text { Population } \\
\text { aged } 65 \text { or } \\
\text { over with } \\
\text { discharge } \\
\text { from the } \\
\text { Emergency } \\
\text { Department }\end{array}$ & $\begin{array}{l}\text { Determine } \\
\text { whether a } \\
\text { telephone } \\
\text { intervention } \\
\text { scheduled by } \\
\text { a nurse will } \\
\text { decrease } \\
\text { readmissions } \\
\text { to the ER } \\
\text { after } 30 \text { days } \\
\text { of discharge }\end{array}$ & $\begin{array}{l}\text { The scheduled } \\
\text { telephone } \\
\text { intervention does } \\
\text { not seem to have } \\
\text { been enough to } \\
\text { decrease } \\
\text { readmissions to the } \\
\text { US; however, it } \\
\text { looks like individuals } \\
\text { who answer the } \\
\text { phone call are more } \\
\text { willing to follow the } \\
\text { recommendations, } \\
\text { decreasing the } \\
\text { likelihood of } \\
\text { returning to the ER. }\end{array}$ \\
\hline
\end{tabular}




\begin{tabular}{|c|c|c|c|c|c|}
\hline Code & Author, year & $\begin{array}{l}\text { Type of } \\
\text { study }\end{array}$ & Participants & Objectives & Main results \\
\hline E2 & $\begin{array}{c}\text { Cossette, S., } \\
\text { Frasure-Smith, } \\
\text { N., } \\
\text { Vadeboncoeur, } \\
\text { A., McCusker, } \\
\text { J. \& Guertin, } \\
\text { M.-C. (2015) }\end{array}$ & $\begin{array}{l}\text { Randomized } \\
\text { trial with } \\
\text { control group }\end{array}$ & $\begin{array}{l}\text { Population } \\
\text { aged } 65 \\
\text { years and } \\
\text { over, who } \\
\text { used the ER } \\
\text { of a hospital }\end{array}$ & $\begin{array}{l}\text { Evaluate the } \\
\text { effectiveness } \\
\text { of nursing } \\
\text { interventions } \\
\text { in the ER, in } \\
\text { reducing } \\
\text { readmissions; } \\
\text { Determine } \\
\text { patients' } \\
\text { perception of } \\
\text { continuity of } \\
\text { care and } \\
\text { understanding } \\
\text { of disease }\end{array}$ & $\begin{array}{c}\text { The chosen } \\
\text { intervention was a } \\
\text { nursing consultation } \\
\text { before discharge } \\
\text { from the ER and two } \\
\text { phone calls as } \\
\text { follow up in } 10 \text { days } \\
\text { after discharge. The } \\
\text { intervention had no } \\
\text { impact on the } \\
\text { primary outcome of } \\
\text { readmissions to the } \\
\text { ER, but } \\
\text { demonstrated a } \\
\text { positive impact on } \\
\text { patients' perception } \\
\text { of continuity of care } \\
\text { and adherence to } \\
\text { medication after } \\
\text { discharge }\end{array}$ \\
\hline \multirow[t]{3}{*}{ E3 } & $\begin{array}{c}\text { Deschodt, M., } \\
\text { Devriendt, E., } \\
\text { Sabbe, M., } \\
\text { Knockaert, D., } \\
\text { Deboutte, P., } \\
\text { Boonen, S., ... } \\
\text { Milisen, K. } \\
\text { (2015) }\end{array}$ & $\begin{array}{l}\text { Prospective } \\
\text { cohort study }\end{array}$ & $\begin{array}{l}\text { Population } \\
\text { aged } 75 \text { or } \\
\text { over who } \\
\text { resorted to } \\
\text { the } \\
\text { Emergency } \\
\text { Department }\end{array}$ & $\begin{array}{l}\text { Compare the } \\
\text { characteristics } \\
\text { of the } \\
\text { population in } \\
\text { question that } \\
\text { is admitted } \\
\text { and } \\
\text { discharged } \\
\text { from the US; }\end{array}$ & $\begin{array}{l}\text { A poor assessment } \\
\text { of the elderly person } \\
\text { and a non-follow-up } \\
\text { after discharge, } \\
\text { increase the risk of } \\
\text { readmission, after } \\
\text { one to three } \\
\text { months. This } \\
\text { suggests that } \\
\text { problems at a } \\
\text { psychosocial, } \\
\text { cognitive and } \\
\text { pathological level } \\
\text { are not taken into } \\
\text { account during the } \\
\text { emergency episode. }\end{array}$ \\
\hline & & & & & $\begin{array}{l}\text { The introduction of a } \\
\text { model of care based } \\
\text { on a holistic } \\
\text { perspective that } \\
\text { includes a } \\
\text { comprehensive } \\
\text { geriatric } \\
\text { assessment (CGA), } \\
\text { is an effective } \\
\text { strategy to avoid } \\
\text { unnecessary } \\
\text { readmissions to the } \\
\text { SU. }\end{array}$ \\
\hline & & & & & $\begin{array}{l}\text { This model allows } \\
\text { the evaluation of the } \\
\text { medical history, the } \\
\text { psychosocial } \\
\text { context and the } \\
\text { functional capacities } \\
\text { of the elderly } \\
\text { person, in order to } \\
\text { develop an } \\
\text { individualized plan } \\
\text { that will predictably } \\
\text { decrease the } \\
\text { number of } \\
\text { readmissions. }\end{array}$ \\
\hline
\end{tabular}




\begin{tabular}{|c|c|c|c|c|c|}
\hline Code & Author, year & $\begin{array}{l}\text { Type of } \\
\text { study }\end{array}$ & Participants & Objectives & Main results \\
\hline E4 & $\begin{array}{c}\text { Hwang, U., } \\
\text { Dresden, S. } \\
\text { M., } \\
\text { Rosenberg, M. } \\
\text { S., et al. } \\
\text { (2018) }\end{array}$ & $\begin{array}{l}\text { Prospective } \\
\text { observational } \\
\text { cohort study }\end{array}$ & $\begin{array}{c}\text { Population } \\
\text { aged } 65 \text { or } \\
\text { over }\end{array}$ & $\begin{array}{l}\text { Examine the } \\
\text { effect of } \\
\text { transitional } \\
\text { nursing care } \\
\text { during an } \\
\text { emergency } \\
\text { episode, in } \\
\text { order to } \\
\text { understand } \\
\text { the risk of } \\
\text { hospitalization } \\
\text { or risk of } \\
\text { readmission } \\
\text { to the ER } \\
\text { after } \\
\text { discharge }\end{array}$ & $\begin{array}{l}\text { The nursing } \\
\text { intervention } \\
\text { consisted of an } \\
\text { evaluation, through } \\
\text { the application of } \\
\text { scales in order to } \\
\text { understand the } \\
\text { evolution of } \\
\text { functional and } \\
\text { cognitive deficits, } \\
\text { physical fragility and } \\
\text { medical } \\
\text { complexities } \\
\text { common in the } \\
\text { elderly in order to } \\
\text { avoid readmissions } \\
\text { in the SU. This } \\
\text { resulted in a } \\
\text { significant decrease } \\
\text { in possible } \\
\text { hospitalizations, and } \\
\text { in readmissions to } \\
\text { the ER at the end of } \\
72 \text { hours and } 30 \\
\text { days after the initial } \\
\text { emergency episode }\end{array}$ \\
\hline E5 & $\begin{array}{l}\text { Legramante, J. } \\
\text { M., Morciano, } \\
\text { L., Lucaroni, } \\
\text { F., Gilardi, F., } \\
\text { Caredda, E., } \\
\text { Pesaresi, A., ... } \\
\text { Palombi, L. } \\
\text { (2016) }\end{array}$ & $\begin{array}{l}\text { Retrospective } \\
\text { study }\end{array}$ & $\begin{array}{c}\text { People aged } \\
65 \text { (or over) } \\
\text { and with } 4 \\
\text { or more } \\
\text { admissions } \\
\text { in a year to } \\
\text { the } \\
\text { emergency } \\
\text { department }\end{array}$ & $\begin{array}{l}\text { Evaluate and } \\
\text { characterize } \\
\text { the } \\
\text { admissions of } \\
\text { people aged } \\
65 \text { and over to } \\
\text { the ER in } \\
\text { order to } \\
\text { identify } \\
\text { clinical and } \\
\text { social } \\
\text { characteristics } \\
\text { related to } \\
\text { frequent } \\
\text { elderly } \\
\text { patients. }\end{array}$ & $\begin{array}{l}\text { The study identified } \\
\text { as risk factors for } \\
\text { readmission to the } \\
\text { ER: the advanced } \\
\text { age of the } \\
\text { population, the lack } \\
\text { of primary care } \\
\text { health units, and } \\
\text { socioeconomic } \\
\text { status. } \\
\text { The lack of } \\
\text { continuity of care } \\
\text { may explain the } \\
\text { high rate of } \\
\text { readmissions to the } \\
\text { ER, as after } \\
\text { discharge, this } \\
\text { population tends to } \\
\text { be readmitted. }\end{array}$ \\
\hline E6 & $\begin{array}{l}\text { Robinson, T. } \\
\text { E., Zhou, L., } \\
\text { Kerse, N., } \\
\text { Scott, J. D. R., } \\
\text { Christiansen, } \\
\text { J. P., Holland, } \\
\text { K., ... Bramley, } \\
\text { D. (2015) }\end{array}$ & $\begin{array}{l}\text { Observational } \\
\text { study without } \\
\text { a control } \\
\text { group. }\end{array}$ & $\begin{array}{c}\text { People aged } \\
65 \text { and over } \\
\text { with } \\
\text { emergency } \\
\text { service } \\
\text { admissions }\end{array}$ & $\begin{array}{l}\text { Determine } \\
\text { which } \\
\text { interventions } \\
\text { allow reducing } \\
\text { the } \\
\text { readmissions } \\
\text { of elderly } \\
\text { people in the } \\
\text { ER at the end } \\
\text { of } 28 \text { days } \\
\text { after the first } \\
\text { episode; as } \\
\text { well as } \\
\text { understanding } \\
\text { how to reduce } \\
\text { readmissions } \\
\text { by applying } \\
\text { the ITC } \\
\text { (Integrated } \\
\text { Transition of } \\
\text { Care) } \\
\text { program }\end{array}$ & $\begin{array}{l}\text { People at high risk } \\
\text { of readmission were } \\
\text { identified, according } \\
\text { to several risk } \\
\text { factors. A telephone } \\
\text { follow-up program } \\
\text { with associated } \\
\text { interventions (ITC) } \\
\text { was applied in order } \\
\text { to provide continuity } \\
\text { of care, concluding } \\
\text { that just follow-up } \\
\text { through telephone } \\
\text { follow-up was not } \\
\text { enough to reduce } \\
\text { readmissions after } \\
28 \text { days. }\end{array}$ \\
\hline
\end{tabular}




\begin{tabular}{|c|c|c|c|c|c|}
\hline Code & Author, year & $\begin{array}{l}\text { Type of } \\
\text { study }\end{array}$ & Participants & Objectives & Main results \\
\hline E7 & $\begin{array}{l}\text { Yao, J-L., } \\
\text { Fang, J., Lou, } \\
\text { Q-Q., \& } \\
\text { Anderson, R. } \\
\text { (2015) }\end{array}$ & $\begin{array}{l}\text { Systematic } \\
\text { literature } \\
\text { review of } \\
\text { prospective } \\
\text { and } \\
\text { retrospective } \\
\text { studies }\end{array}$ & $\begin{array}{l}\text { Based on } \\
\text { studies } \\
\text { carried out } \\
\text { with people } \\
\text { aged } 65 \text { and } \\
\text { over with } \\
\text { admissions } \\
\text { to the } \\
\text { emergency } \\
\text { department } \\
\text { in Canada, } \\
\text { Belgium, } \\
\text { Italy, the } \\
\text { Netherlands, } \\
\text { Switzerland, } \\
\text { the United } \\
\text { Kingdom } \\
\text { and } \\
\text { Germany }\end{array}$ & $\begin{array}{l}\text { Evaluate the } \\
\text { "Identification } \\
\text { Tool for } \\
\text { Elderly at Risk } \\
\text { (ISAR)" in } \\
\text { identifying the } \\
\text { elderly people } \\
\text { at risk of } \\
\text { adverse } \\
\text { results after } \\
\text { admission to } \\
\text { the ER. }\end{array}$ & $\begin{array}{l}\text { ISAR has questions } \\
\text { about functional } \\
\text { dependence, recent } \\
\text { hospitalizations, } \\
\text { impaired memory } \\
\text { and vision and } \\
\text { polymedication. It is } \\
\text { useful to identify } \\
\text { high-risk elderly } \\
\text { people admitted to } \\
\text { the ER, but it is not } \\
\text { enough to predict } \\
\text { the adverse health } \\
\text { outcomes of after } \\
\text { discharge, in order } \\
\text { to prevent } \\
\text { readmission. } \\
\text { ISAR should be } \\
\text { modified according } \\
\text { to each country and } \\
\text { the health } \\
\text { conditions specific } \\
\text { to each country } \\
\text { where the } \\
\text { instrument is used. } \\
\text { It is advisable to use } \\
\text { ISAR when making } \\
\text { a decision, in order } \\
\text { to facilitate the } \\
\text { transition of care. }\end{array}$ \\
\hline
\end{tabular}

\section{Risk Factors of the Elderly for Readmissions to the Emergency Room}

Considering the typology of the population concerned, it is expected that the elderly population is more vulnerable than the younger population, due to the aging process itself. Thus, there is a need to identify the risk factors of the elderly person, which lead to readmissions to the ER, after a first occurrence for the same or for another reason. This identification of risk factors becomes important, as it is from there that strategies are implemented to ensure continuity of care after discharge from the ER. According to Legramante et al. (2016), the frequent use of the ER by the elderly population and overpopulation in these services, lead to early discharge and a lack of follow-up care by this same population. This causes an increase in health spending and a decrease in the quality of care.

Robinson et al. (2015) indicates the use of a risk assessment model when the elderly person is admitted to the ER. This model has the sole objective of identifying people at high risk of being readmitted to the ER after discharge. The use of this model applies several variables that include: the person's demographic information (gender, age, location), health history (personal history), as well as chronic diseases (chronic obstructive pulmonary disease, heart failure, cancer) and medication (multidrug and risk medication).

Deschodt et al. (2015) also apply what they call a comprehensive geriatric assessment, based on a holistic perspective of the elderly, to establish the characteristics of the elderly population that uses the ER. This assessment goes through a multidimensional process that determines the medical history of the elderly person, the psychosocial context, and their functional capacities. This assessment adds variables, in addition to those mentioned by Robinson et al (2015), such as the person's life situation (home, home with caregiver, 
homes), dependence on activities of their daily life (use of the Katz scale), the existence of a previous follow-up of home nursing, physical therapy, dependence on instrumental activities of their daily living (if there is provision of daily meals at home, domestic help at home, such as cleaning, shopping and finances), the person's mobility, pain, nutritional status, cognitive function, risk of falling, treatment priority in the ER, using the Emergency Service Index (ESI), an index with five levels (5 - less urgent, 1 - very urgent), which is a screening algorithm used in the ER.

Both Hwang et al. (2018) and Yao et al. (2015) identify the risk factors of the elderly population for readmissions to the SU using the ISAR (Identification of Seniors At Risk) tool. This tool includes six items, with "yes" or "no" answers, related to functional dependence, recent hospitalizations, impaired memory and vision and the use of polymedication. The total score varies between 0 and 6 . This tool proves to be useful in identifying elderly people at high risk of being readmitted to the ER.

In summary, according to the bibliographic research, several risk factors of the elderly person for readmissions in the ER are identified, the main factors being identified: the person's life history, such as the situation of life and housing, their personal history and their level of dependence, their usual medication (particularly in polymedicated people), their cognitive function and the risk of falling. It should also be noted that in the various studies analyzed, to determine the risk of readmission, it is common to use several scales, including the Katz scale, ESI and ISAR.

\section{Strategies to be Implemented: Nursing Care that Promotes a Safe Transition}

Once the problem is understood, the risk factors inherent to the study population, it is pertinent to understand what are the strategies and nursing care that promote a safe transition, which are complemented by the scientific evidence found during the research process. In the study by Biese et al. (2018), the effect of a follow-up phone call from one to three days after the individual's episode with the ER was studied. This call was made by a trained nurse who used an existing questionnaire, in order to identify possible obstacles to a safe transition for the community, such as the acquisition and reconciliation of medication, post discharge indications and access to medical monitoring, also giving assistance in making appointments. After 30 days, an interview was conducted to see if the participants had felt the need to return to the ER, to primary health care, or to any specialist or if they had any problems related to their medication regimen. The authors concluded that the studied intervention did not reduce readmissions to the ER in this study population, with $15.8 \%$ of the study group and $14.4 \%$ of the control group aged between 65 and 74 years returning to the ER, were hospitalized, or died within 30 days and the same happened to $14.9 \%$ of the study group and $16.6 \%$ of the control group aged 75 or over. Despite the results, the study still indicates as a hypothesis, that it is possible that individuals who answer the phone call are more willing to follow the recommendations, with a lesser probability of returning to the ER.

Cossette et al (2015) developed a short-term intervention that contained three moments of contact with the individual. The first contact would be at the time of discharge and then two phone calls would be made: the first two to four days after discharge and the second seven to ten days after discharge. These interventions were performed by a nurse who assessed the individuals' coping capacity to deal with concerns and their readiness or lack of readiness, for returning home; disease and symptom management; treatment management; activities of daily living (ADL) and instrumental activities of daily living (IADL); emotions and cognition; resources; and the health system. Through this tool, patients were considered to be without risk, with present risk but with coping strategies, with risk, or not assessed. If an individual was considered at risk in any of the previous items, they were submitted to nursing interventions, individualized to each patient, which included: teaching, normalizing, listening, comforting, confronting, advising, recommending, warning, giving positive feedback, referencing and reinforce the use of other external resources. If necessary, individuals could contact the nurse to ask any questions or concerns. For a 
better individualization of interventions, nurses had access to the patient's process, namely, medical diagnosis, procedures performed, treatment, medication, and discharge planning. According to the study, the interventions had no effect at the level of primary objectives, that is, in reducing readmissions to the ER. However, the present study demonstrated that the interventions had a positive effect on individuals, who acquired a greater understanding of continuity of care, their self-care capabilities, in controlling anxiety and depressive symptoms, together with a better perception of what it's like to be sick.

Deschodt et al. (2015), as in other studies, also suggest a telephone follow-up after discharge from the ER, after one month and after three months. After defining the risk factors for readmission to the ER, the authors suggest that the comprehensive geriatric assessment they apply is important in identifying the people at greatest risk of readmission, which will facilitate the follow-up given in the community.

According to the study by Hwang et al. (2018), a program was implemented with a nurse who is an expert in transitional care. The program by the name of GEDI WISE (Geriatric Emergency Department Innovations in Care through Workforce, Informatics, and Structural Enhancements) was applied in three hospitals. The nurse has the function of assessing the functional and cognitive deficit, the physical weaknesses, and the complexities of the medical forum, of the elderly person over 75 years old who resorted to the ER. In this way, the needs of each elderly person were identified and the resources available in hospitals and in the community, in order to respond to these needs. The nurse applied tests / scales to assess cognitive function, delirium, functional status (Katz scale), risk of falling, transition of care (Care Transitions Measure scale - 3 ) and caregiver fatigue. After this assessment, a multidisciplinary intervention was initiated, with the resources available in the hospital concerned or in the community, which best fit the person's needs. In hospitals where GEDI WISE was used, the transitional care nurse evaluated about $10 \%$ of the individuals who resorted to the ER and was able to reduce the risk of readmission of these individuals by five to $16 \%$.

In the study by Robinson et al. (2015) individuals who were identified as having a high risk of readmission in the ER had automatically raised interventions, even during the emergency episode. These interventions were related to nutrition, the review of the person's health care, medication reconciliation and education through a pharmacist. After discharge, individuals returning to their home received two telephone contacts on the first and third day after discharge. These contacts were made by a team of experienced community nurses and were intended to identify problems that had not been resolved during discharge planning, as well as to help with the person's self-management and to ensure social and health support. These results were later forwarded to primary health care. After these interventions, it was found that a quarter of the individuals were readmitted to the hospital and a third resorted to ER up to 28 days after discharge. $65 \%$ of the individuals had access to the telephone follow-up and, of the individuals contacted, $68 \%$ received a telephone call, $24 \%$ two and $8 \%$ three or more calls. Through the calls, needs were identified in terms of medication, personal or functional management and physical or mental health. Only $16 \%$ of these contacted individuals asked for referral to another health service.

In summary, according to the bibliographic research, the strategies and care that promote a safe transition to be implemented undergo an appropriate follow-up, either by telephone calls by expert teams in care transition or by the resources available in the community that interconnect with the ER. This follow-up has as main objective to understand what happens to the individual after having used the ER, if there is a need for readmission or readmission in the ER or if the follow-up by primary health care is having the intended effect. The different studies, explained above, also identify that a good assessment, in a holistic way, where the assessment of the different aspects of the person is verified (functional status, cognitive function, medication, risk of falling, among others), which allows for more individualized interventions for each person. In these interventions, teaching the individual and / or caregiver, positive feedback, referral to other health services and encouraging selfmanagement are distinguished. Although the interventions implemented did not reduce the number of readmissions or visits to the ER, there are several gains for individuals, such as 
being able to recognize the disease itself and to follow the recommendations given by nurses.

\section{Discussion}

Deschodt et al. (2015), Legramante et al. (2016) and Yao et al. (2015), reinforce that a holistic assessment of the elderly, including their various personal backgrounds, polymedication, the level of dependence, cognitive function, among others, allows the identification of risk factors for readmission to the ER. In this way, resources on the part of the community will be able to intervene at a more individualized level, using the various means available. For this to be possible, it is essential that the nurse takes on this person's assessment intervention in order to understand all the person's variables, because an incomplete assessment can lead to inadequate follow-up, which will occur, in most cases, in a readmission to the ER. In the analyzed literature, several tools are described that help to carry out this evaluation, such as the ISAR, ESI, Katz scales, among others. The correct identification of the risk factors will allow us to identify the focus of action that needs more vigilance, by maintaining a nursing monitoring according to the risk factors of each individual, in the long run, they will decrease readmissions to the ER. Thus, according to the analysis of the studies, the assessment of the elderly patient in an emergency situation must consider the following factors: age, their current life situation, personal history, and chronic diseases (chronic obstructive pulmonary disease, heart failure heart disease, cancer, also type 2 diabetes mellitus and chronic renal failure, medication, cognitive function and risk of falling.

Deschodt et al. (2015), Hwang et al. (2018), and Robinson et al. (2015) refer that the identification of risk factors for readmissions to the ER is essential for implementing strategies that guarantee the continuity of care in the community. Thus, Direção-Geral da Saúde (2017) recommends that the health care transition is a moment that cannot be undervalued, since it is considered a situation that adds some vulnerability to the person. The care transition must be carried out strictly, since it "concerns the maintenance of effective communication between health professionals" (Direção-Geral da Saúde 2017, p. $5)$, thus allowing a safe and effective continuity of care.

The literature recognizes interventions with different levels of effectiveness, and it is up to the nurse to choose the ones that best suit the care recipient. Cossette et al. (2015) apply an intervention that involves telephone calls directed to the promotion of coping skills, the management of the disease and symptoms, and the general assessment of the person. That said, nurses' interventions must include teaching, counseling, listening, referencing, and reinforcing the use of other community resources. Like Biese et al. (2018) and Deschodt et al. (2015), these also suggest a telephone follow-up after discharge from the ER. It can be concluded that the use of new technologies is increasingly valued in health care, depending on the person which facilitates the monitoring and allows the nurse to realize the person's current state and understand whether the interventions are or not effective. Thus, an increase in the person's trust in the nurse is observed, as the nurse can demonstrate a trust that is visible to the person.

Robinson et al. (2015) and Hwang et al. (2018) show the existence of a nurse or a nursing team who are experts in the transition of care, who carry out a holistic assessment of the person, plan discharge and mobilize the most appropriate community resources. It is noted here that these nurses assume a role of liaison between the ER and the community and that they have a significant impact in reducing readmissions.

\section{Conclusions}

As for the risk factors predisposing to increase the likelihood of a person using the $E R$, the importance of rigorously assessing personal history, polymedication, current life situation, age, level of dependence, risk of falling is emphasized, the cognitive function, and the evidence mentions several tools that help to carry out this evaluation, such as the ISAR, 
ESI, Katz scales, among others. As for the nursing interventions contemplated in the research results, an intervention that involves follow-up phone calls is highlighted, where subjects such as the promotion of coping capacity, the management of the disease and symptoms and a general assessment of the person are addressed, and nursing interventions include teaching, counseling, listening, referencing and reinforcement in the use of community resources and the existence of a nurse or a nursing team who are experts in the transition of care, who perform functions exclusively at the level of health assessment of the person, discharge planning and referral to community resources, this being the intervention that had the most significant impact in terms of the decrease in readmissions to the ER.

As for the adversities found during the elaboration of the RIL, the group highlights the scarcity of information found that answers the PICo question, namely regarding the population group on which the question is concerned. It is suggested that the search be extended to more databases. As a recommendation for future research and given the scarcity of information found on the subject, it is recognized that this theme needs further investigation, and investment in research sensitive to this theme is suggested, carrying out more extensive studies and with a better level of evidence, - to continue the production of knowledge in relation to this topic, so that eventually we can reach more solid conclusions, which will certainly impact better nursing care.

\section{References}

Azaredo, Z. (2014). The elderly in a hospital emergency service. Journal of Aging and Innovation, 2(4), 20-26. http://www.journalofagingandinnovation.org/wp-content/uploads/ldososurgencia.pdf

Azevedo, M. S. (2015). O envelhecimento ativo e a qualidade de vida: Uma revisão integrativa [Active aging and quality of life: An integrative review]. [Unpublished master's thesis]. Nursing School of Porto.

Biese, K. J., Busby-Whitehead, J., Cai, J., Stearns, S. C., Robberts, E., Mihas, P., Emmett, D., Zhou, Q., Farmer, F., \& Kizer, J. S. (2017). Telephone follow-Up for older adults discharged to home from the emergency department: A pragmatic randomized controlled trial. Journal of the American Geriatrics Society, 66(3), 452-458. https://doi.org/10.1111/jgs.15142

Brazão, M. L., Nóbrega, S., Bebiano, G., \& Carvalho, E. (2016). Activity of hospital emergency services. Medicina Interna, 23(3), 8-14. https://www.spmi.pt/revista/vol23/vol23_n3_2016_08_14.pdf

Cossette, S., Frasure-Smith, N., Vadeboncoeur, A., McCusker, J., \& Guertin, M. (2015). The impact of an emergency department nursing intervention on continuity of care, self-care capacities and psychological symptoms: Secondary outcomes of a randomized controlled trial. International Journal of Nursing Studies, 52(3), 666-676. https://doi.org/10.1016/j.ijnurstu.2014.12.007

Deschodt, M., Devriendt, E., Sabbe, M., Knonkart, D., Deboutte, P., Boonen, S., Flamaing, J., \& Milisen, K. (2015). Characteristics of older adults admitted to the emergency department (ED) and their risk factors for ED readmission based on comprehensive geriatric assessment: A prospective cohort study. BMC Geriatrics, 15(24). https://doi.org/10.1186/s12877-015-0055-7

Direção-Geral da Saúde. (2017). Comunicação eficaz na transição de cuidados de saúde [Effective communication in the health care transition]. https://www.dgs.pt/directrizes-da-dgs/normas-ecirculares-normativas/norma-n-0012017-de-08022017-pdf.aspx

Hwang, U., Dresden, S. M., Rosenberg, M. S., Garrido, M. M., Loo, G., Sze, J., Gravenor, S., Courtney, D. M., Kang, R., Zhu, C. W., Vargas-Torres, C., Grudzen, C. R., \& Richardson, L. D. (2018). Geriatric emergency department innovations: Transitional care nurses and hospital use. Journal of American Geriatrics Society, 66(3), 459-466. https://doi.org/10.1111/jgs.15235

Legramante, J. M., Morciano, L., Lucaroni, F., Gilardi, F., Caredda, E., Pesaresi, A., Coscia, M., Orlando, S., Brandi, A., Giovagnoli, G., Lecce, V. N., Visconti, G., \& Palombi, L. (2016). Frequent use of emergency departments by the elderly population when continuing care is not well established. PLoS One, 11(12). https://doi.org/10.1371/journal.pone.0165939 
Mendes, K. D., Silveira, R. C., \& Galvão, C. M. (2008). Revisão integrativa: Método de pesquisa para a incorporação de evidências na saúde e na enfermagem [Integrative review: Research method for incorporating evidence in health and nursing]. Nursing Text \& Context, 12(4), 510. https://doi.org/10.1590/S0104-07072008000400018

Robinson, T. E., Zhou, L., Kerse, N., Scott, J. D., Christiansen, J. P., Holland, K., Armstrong, D. E., \& Bramley, D. (2015). Evaluation of a New Zealand program to improve transition of care for older high risk adults. Australasian Journal of Ageing, 34(4), 269-274. https://doi.org/10.1111/ajag.12232

Statistics Portugal (INE). (2017). Projeções de População Residente [Projections of Resident Population]. Statistics Portugal (INE). https://www.ine.pt/ngt_server/attachfileu.jsp?look_parentBoui=289229688\&att_display=n\&att _download=y

The Joanna Brigs Institute. (2011). Joanna bigs institute reviewers' manual (2011 ed.). The Joanna Brigs Institute.

Yao, J., Fang, J., Lou, Q., \& Anderson, R. M. (2015). A systematic review of the identification of seniors at risk (ISAR) tool for the prediction of adverse outcome in elderly patients seen in the emergency department. International Journal of Clinical and Experimental Medicine, 8(4), 4778-4786. http://www.ijcem.com/files/ijcem0005825.pdf 